\title{
Lelki egészség Nyíregyháza lakosai körében
}

\author{
Mental Health among residents of Nyíregyháza
}

Szerzők: $\quad$ Sárváry Andrea $₫$, Majer Rékaa ${ }^{a}$, Jávorné Erdei Renátab

a: Debreceni Egyetem Egészségügyi Kar, Szociális és Társadalomtudományi Intézet, Pszichológia Tanszék, b: Debreceni Egyetem Egészségügyi Kar, Egészségtudományi Intézet, Védőnői Módszertani és Népegészségtani Tanszék

Beküldve: $\quad$ 2019. 09. 15.

doi: $\quad$ 10.24365/ef.v60i5.519

\begin{abstract}
Összefoglaló:
Bevezetés: A lelki egészséget nem lehet különválasztani a demográfiai változóktól, életmódtényezőktől és a fizikai paraméterektől, mert ezek dinamikus kölcsönhatásban vannak egymással. Kutatásunk célja annak kiderítése volt, hogy Nyíregyháza város lakossága milyen mutatókkal rendelkezik a lelki egészség szempontjából: a lakosok hogyan jellemzik magukat a jóllét és lelki egészség konstruktumában, mennyire élik meg stresszesnek az életüket, hogy alakulnak a depressziót mérő mutatók, és mennyire érzik, hogy értelmes életet élnek.
\end{abstract}

Módszertan: Kutatásunkban 386 nyíregyházi lakos vett részt: 142 férfi $(36,8 \%)$ és 244 nő (63,2\%). Átlag életkor 49,96 év. A következő mérőeszközöket alkalmaztuk: WHO Általános Jóllét Skála (WBI-5), Rövidített Beck Depresszió Kérdőív, Rövidített Stressz és Megküzdés Kérdőiv élet értelmességét mérő alskála (BSCI-LM), Észlelt Stressz Kérdőív (PSS), Lelki Egészség Kérdőiv (GHQ) és az Egészségi Állapot Önbecslése. Leíró statisztikát, 2 mintás t-próbát, ANOVA próbát és korrelációanalízist alkalmaztunk.

Eredmények: A Jóllét Skála átlagértéke az egészségi állapot romlásával csökken, a jövedelem emelkedésével emelkedik $(p<0,0001)$. A depressziós tünetek súlyossága szignifikánsan nő az életkor emelkedésével ( $p=0,002)$ és az egészségi állapot romlásával $(p<0,0001)$. Az élet értelmességét mérő alskála átlagértéke szignifikánsan emelkedik a nettó jövedelem emelkedésével $(p=0,048)$ és az egészségi állapot egyre kedvezőbb megítélésével $(p<0,0001)$. Szignifikánsan magasabb a stressz-szintje azoknak, akik saját egészségi állapotukat nagyon rossznak értékelik $(p<0,005)$, és nagyobb mentális funkciócsökkenés tapasztalható az ő esetükben $(p<0,0001)$. Az észlelt stressz szintje és a mentális funkciócsökkenés a jövedelmi kategóriák közül a felsőközéposztályban szignifikánsan emelkedettebb.

Következtetés: Eredményeink szerit az idősebb kor, a kedvezőtlennek ítélt egészségi állapot és az anyagi helyzet negatív módon befolyásolják a lelki egészséget. Éppen ezért az idősek, a betegek és a kedvezőtlen anyagi helyzetben levő személyek pszichés támogatására az egészségügyi és szociális szakmában dolgozóknak kiemelt figyelmet kell szentelniük. Vizsgálatunk alapján úgy túnik, hogy a megélt élethelyzet szubjektív terhe a meghatározó, és nem az objektív demográfiai mutatók.

Kulcsszavak: lelki egészség; stressz; jóllét; depresszió

\section{Summary:}

Introduction: Mental health cannot be separated from demographic variables, lifestyle factors and physical parameters, because they interact dynamically. The aim of this study was to reveal what indicators the population of the city of Nyíregyháza has in terms of mental health: how inhabitants describe themselves in the construct of well-being and mental health, how stressful their lives are, if they are living meaningful lives. 
Methods: Three hundred and eighty-six residents of Nyíregyháza participated in this study (male: 142, 36,8\%, female: 244, 63,2\%; mean age: 49,96 years). The following measures were used: WHO Well-Being Scale, Short Form of Beck Depression Questionnaire, the life meaning subscale from the Brief Stress and Coping Inventory, Perceived Stress Questionnaire, Mental Health Questionnaire and Self-esteem for Health. Descriptive statistics, independent T-test, ANOVA and correlation analysis were used.

Results: The mean value of the Well-Being Scale decreases with deterioration in health status and increases with income $(p<0.0001)$. The severity of depressive symptoms increases significantly with higher age $(p=0.002)$ and worsening of health $(p<0.0001)$. The mean value of life meaning subscale increases significantly with the increase of income $(p=0.048)$ and with an improvement in health status $(p<0.0001)$. Significantly higher stress levels were found for those who were rated their own health very poor $(p<0.005)$ and who had a greater mental impairment $(p<0.0001)$. The level of perceived stress and mental decline among income categories is significantly higher in the upper middle class.

Conclusion: Our findings suggest that older age, poor health, and financial status have a negative impact on mental health. Therefore, psychiatric support for the elderly, patients and people in financial disadvantages should be given special attention to health and social care professionals. Based on our analysis, the subjective burden of living life seems to be the determining factor, not the objective demographic indicators.

Keywords: mental health; stress; well-being; depression

\section{BEVEZETÉS}

Az Egészségügyi Világszervezet (World Health Organisation, WHO) 1948-ban az egészség fogalmát úgy határozta meg, mint „teljes testi, lelki és társadalmi jóllét állapota", és nem egyszerúen a betegségek vagy fogyatékosságok hiánya. A definíció egyértelműen kifejezi, hogy az egészségnek több dimenziója van: testi, lelki és társas, szociális, társadalmi. ${ }^{1,2}$ A lelkileg egészséges embereket általános jóllétérzés, érzelmi stabilitás, önmaguk elfogadása, reális önértékelés és hatékony megküzdés jellemzi. ${ }^{3,4}$

Az egészség komplex szemlélete alapján a mentális és lelki egészség igen nagy szerepet tölt be, amelyeket nem lehet különválasztani a demográfiai változóktól, életmód-tényezőktől és a fizikai paraméterektől, hiszen ezek dinamikus kölcsönhatásban vannak egymással.

A WHO legújabb meghatározása szerint a lelki/ mentális egészség a jóllét állapota, melyben a személy megvalósítja képességeit, meg tud küzdeni az élet átlagos stresszeivel, képes produktívan és eredményesen dolgozni, és hozzájárulni a közösség múködéséhez. ${ }^{5} \mathrm{~A}$ definíciója alapján a lelki egészség nem csupán a mentális eredetű megbetegedések hiánya. Ideértjük a szubjektív jóllétet, és az egyéneknek azt a benyomását, hogy mennyire érzik azt, hogy értelmes életet élnek, és képesek kiteljesedni a világban. A mentális egészségen belül megkülönböztetünk pozitív és negatív aspektusokat. A pozitív mentális egészség olyan tényezőket foglal magába, mint a jóllét, érzelmi egyensúly, boldogság, optimizmus és a stresszel, kedvezőtlen élethelyzetekkel való megbirkózás képessége. A negatív mentális egészség a mentális zavarokra, problémákra, tünetekre vonatkozik. ${ }^{6}$

A mentális egészséghez szorosan kapcsolódik az életminőség fogalma. Az Egészségügyi Világszervezet az életminőséget az alábbiak szerint határozza meg: "Az életminőség az egyén észlelete az életben elfoglalt helyzetéről, ahogyan azt életterének kultúrája, értékrendszerei, valamint saját céljai, elvárásai, mintái és kapcsolatai befolyásolják. Szélesen értelmezett fogalom, amely bonyolult módon magába foglalja az egyén fizikai egészségét, pszichés állapotát, függetlenségének fokát, társadalmi kapcsolatait, személyes hitét, valamint a környezet lényeges jelenségeihez füződő viszonyát". ${ }^{5}$

Az elmúlt évek nemzetközi és hazai kutatási eredményei rámutattak arra, hogy a kelet-közép-európai országokra jellemző morbiditási és mortalitási krízis hátterében alapvető a lelki és magatartási tényezők szerepe. A magyar lakosság körében Kopp és munkatársai által végzett kiterjedt vizsgálatok 
bizonyították, hogy a viszonylag rosszabb szociálisgazdasági helyzet nem önmagában, hanem elsősorban a depressziós tünetegyüttes közvetítésével eredményez magasabb megbetegedési arányokat. Tehát az adott élethelyzet szubjektív átélése a lényeges tényező. Ha egy élethelyzetet újszerűnek vagy várhatóan veszélyesnek minősítünk, kétféle választ adhatunk. Amennyiben úgy érezzük, a helyzet megoldható vagy elkerülhető, aktív magatartással reagálunk, elkerüljük az adott helyzetet, vagy aktívan cselekszünk a megoldása érdekében. Így a helyzet kontrollálhatóságát éljük meg. Ha azonban egy élethelyzettel kapcsolatban azt tapasztaljuk, hogy megoldhatatlan számunkra, semmilyen aktivitást nem vagyunk képesek tenni, hogy változás következzen be, erős szorongásos reakció indul be, mely tanult tehetetlenséggel párosulva depressziós tünetegyüttest vált ki.?

A fenti jelenséghez szorosan kapcsolódik a krónikus stressz fogalma. Selye eredeti elképzelése szerint a stressz a szervezet nem specifikus válasza minden olyan ingerre, amely kibillenti egyensúlyi állapotából, és alkalmazkodásra készteti. ${ }^{8}$ Mára már tudományos eredmények bizonyítják, hogy a krónikus stressz igen komoly szerepet játszik a testi és lelki egészségi állapot alakulásában. ${ }^{9}$ Annak meghatározása, hogy egy adott egyénre milyen mértékú stressz hat és ez milyen okokból ered, illetve milyen hatásai vannak, kiemelt jelentőségű az egészségi állapottal kapcsolatos paraméterek szempontjából, és az egészséggel kapcsolatos döntéseket is jelentős mértékben meghatározza.

Kutatásunkban arra voltunk kíváncsiak, hogy Nyíregyháza város lakossága milyen mutatókkal rendelkezik a lelki egészség szempontjából. Vizsgáltuk, hogy a lakosok hogyan jellemzik magukat a jóllét és lelki egészség konstruktumában, mennyire élik meg stresszesnek az életüket, hogy alakulnak a depreszsziót mérő mutatók, és mennyire érzik, hogy értelmes életet élnek. Emellett feltérképeztük a fenti lelkiegészség-mutatók kapcsolatait a demográfiai változókkal, életmódtényezőkkel és egyéb fizikai paraméterekkel. Célunk az volt, hogy pontosabban lássuk, milyen tényezők járulnak hozzá a nyíregyházi lakosok lelki egészségének alakulásához, ezek milyen következményekkel járnak. Mindezt azzal a legfőbb célkitűzéssel végeztük, hogy képet kapjunk arról, hogy a nyíregyházi lakosok lelki egészségének fejlesztése céljából milyen programot lenne érde- mes kidolgozni, mely pontosan azokat a problémákat ragadja meg, amelyek hozzájárulnak a lelki egészségük kialakításához és hosszú távú fenntartásához.

\section{MÓDSZERTAN}

A mintavétel módszere és a minta jellemzői a Takács és mtsai által írt cikkben részletesen megtalálhatók.

\section{Észlelt Stressz Kérdőív (PSS)}

Az Észlelt Stressz Kérdőívet (Perceived Stress Scale, PSS) széles körben alkalmazzák egészséges és beteg populációban egyaránt a krónikus stressz hatásainak vizsgálatára. ${ }^{10} \mathrm{~A}$ kérdőív az elmúlt hónap időszaka alapján kérdez rá arra, hogy a személy szubjektíven mennyi stresszhelyzetet élt át, menynyire tartja saját jelenlegi élethelyzetét kiszámíthatatlannak, befolyásolhatatlannak, túlterheltnek. Jelen vizsgálatunkban a 4 tételes, rövidített verziót használtuk. A kérdőív 5 fokú Likert-skálán mér (soha=0, szinte soha=1, néha=2, elég gyakran=3, nagyon gyakran=4). Az egyes tételeknél a magasabb pontszám jelez nagyobb stressz-szintet, illetve hatékonyabb megküzdést. Az összesített pontszám az észlelt stressz globális mutatója. ${ }^{11}$

\section{Lelki Egészség Kérdőív (GHQ)}

Az Általános Egészség Kérdőív (General Health Questionnaire, GHQ) elsősorban a lelki egészség vizsgálatára alkalmas, azon belül is a hangulati zavarokra jellemző lelki egészségproblémák önbecslésére. ${ }^{12}$ Kutatásunkban a 12 tételes változatot használtuk. ${ }^{13} \mathrm{~A}$ kérdőív 4 pontos Likert-skálán mér, ahol a minimum pont 12 , a maximum 48 . A Lelki Egészség Kérdőívnek többféle értékelési változata ismert. A legelterjedtebb módszer az egyes tünetekre vonatkozó pozitív válaszlehetőségek (ha többször vagy sokkal többször fordult elő, mint általában) 1-re kódolása, míg a többi válaszlehetőség nulla pontot kap (0-0-1-1). A pontok összeadásával tulajdonképpen a tünetek számát kapjuk meg, amely minél nagyobb, annál inkább valószínűsíti a mentális funkciócsökkenést. Küszöb-pontértékként a magyar validálás során az 5-ös értéket határozták meg. 
WHO Általános Jóllét Skála (WBI-5)

A WHO Általános Jóllét Skálájának (WHO Well-Being Scale) 5 tételes változata a válaszadók legutóbbi 2 hétben tapasztalt általános közérzetéről nyújt információt. ${ }^{14}$ A tételek tartalmát a válaszadók 4 fokú skála mentén ítélhettek meg: 0=egyáltalán nem jellemző, $1=$ =alig jellemző, $2=$ =jellemző, $3=$ teljesen jellemző. $A z$ elérhető minimum pontszám 0 , az elérhető maximum pontszám 15. A magasabb pontszámok jelentik a pozitívabb, kedvezőbb pszichológiai állapotot. Korábbi kutatások a skála megbízhatóságát igen jónak találták. ${ }^{14}$

\section{Rövidített Beck Depresszió Kérdőív}

A Rövidített Beck Depresszió Kérdőív (Short Form of Beck Depression Questionnaire) a depresszió különböző tüneteire kérdez rá (pl. szociális visszahúzódás, döntésképtelenség, alvászavar, fáradékonyság, túlzott aggódás a testi tünetek miatt, munkaképtelenség, pesszimizmus, elégedetlenség, öröm hiánya, önvádlás). ${ }^{15,16} \mathrm{~A}$ rövidített változat 9 tételt tartalmaz, melyet a válaszadók 4 fokú skála mentén ítélnek meg (1=egyáltalán nem jellemző, $2=a$ alig jellemző, 3 =jellemző, $4=$ teljesen jellemző). ${ }^{17,18}$ $A z$ elérhető minimum pontszám 9, az elérhető maximum pontszám 36. A magasabb pontszám több depressziós tünet meglétére utal (0-9 pont között: normál érték, 10-18 pont között: enyhe depresszió, 19-25 között: középsúlyos depresszió, 26 pont felett: súlyos depresszió). A skála korábbi alkalmazásaiban a belső megbízhatóság magas volt. ${ }^{19}$

\section{A Rövidített Stressz és Megküzdés Kérdőív élet értelmességét mérő alskálája (Brief Stress and Coping Inventory - Life Meaning; BSCl-LM)}

A Rövidített Stressz és Megküzdés Kérdőív életcél és kapcsolatok alskálájából vett 8 kérdéssel mértük a válaszadók élet értelmességének megélt szintjét. 20,21 A tételek tartalmát a válaszadók háromfokú skála mentén itélhették meg ( $0=$ ritkán, 1=néha, 2=gyakran). A mérőeszköz belső megbízhatósága a korábbi hazai, valamint határon túli, de magyar nyelvű kutatásokban elfogadható volt. 16,22,23,24

\section{Egészségi állapot önbecslése}

Az egészségi állapot önbecslésének jelentőségét számos korábbi kutatás igazolta, és a Hungarostudy 2002-es kutatásban is alkalmazták. ${ }^{25,14}$ Vizsgálatunkban ezzel kapcsolatosan a következő kérdést tettük fel: „Összességében hogyan minősíti saját egészségi állapotát?" A válaszadók 5 fokú skálán (válaszkategóriák: nagyon rossz, rossz, elfogadható, jó, nagyon jó) értékelhették egészségi állapotukat.

\section{Statisztikai elemzés}

Az adatokat az SPSS programcsomaggal és az Excel programmal elemeztük. Leíró statisztikát, 2 mintás T-próbát, ANOVA próbát és korrelációanalízist alkalmaztunk.

A WHO Általános Jóllét Skála, a Rövidített Stressz és Megküzdés Kérdőív élet értelmességét mérő alskálájának tételeiből skálát készítettünk. Mindkét skála belső megbízhatóságát nagyon jónak (Cronbachalfa érték $>0,7)$ találtuk. A skálák átlagértékeit 2 mintás T-próbával összehasonlítottuk a férfiak és a nők között, valamint az ANOVA próbával az egyéb változók mentén (nem, életkor szerinti csoportok, iskolai végezettség, családi állapot, szubjektív egészségi állapot, nettó jövedelem).

A szubjektív egészség utolsó két válaszkategóriáját az alacsony elemszám miatt összevontuk, így 4 válaszkategóriával végeztük el a számításokat.

Az Észlelt Stressz Kérdőív és a Lelki Egészség Kérdőív változóit a demográfiai változók (nem, kor, családi állapot, iskolai végzettség, szubjektív egészség, nettó jövedelem) mentén elemeztük.

\section{EREDMÉNYEK}

Kutatásunkban a 386 fő vett részt: 142 férfi $(36,8 \%)$ és 244 nő (63,2\%). Átlag életkor 49,96 év (20 és 92 év között). A minta további szocidemográfiai jellemzőit az 1. táblázatban foglaltuk össze.

WHO Általános Jóllét Skála (WBI-5)

A teljes minta átlaga 8,47 . Nem találtunk szignifikáns különbséget a nem $(p=0,212)$, a különböző iskolai végzettség $(p=0,157)$, a családi állapot 
$(p=0,317)$ és a korcsoportok $(p=0,057)$ szerint. Ugyanakkor szignifikáns különbséget találtunk a nettó jövedelem $(p<0,0001)$ és az egészségi állapot alapján elkülöníthető $(p<0,0001)$ csoportok általános jól-lét átlagértékei között. [2. táblázat] A legmagasabb nettó jövedelemmel rendelkezők átlagértéke a legmagasabb $(M=9,49)$, és a legalacsonyabb a nettó jövedelemmel rendelkezők átlagértéke a legalacsonyabb $(M=6)$. Az egészségi állapot romlásával szignifikánsan csökken az általános jóllét átlagértéke (10,69-ről 5-re, p<0,0001).

\section{Rövidített Beck Depresszió Kérdőív}

A teljes minta átlaga ( $M=12,318)$ enyhe depressziós állapotot jelez. Nem találtunk szignifikáns különbséget a nem $(p=0,216)$, a különböző iskolai végzettség $(p=0,327)$, a családi állapot $(p=0,573)$ és a nettó jövedelem $(p=0,090)$ szerint.

A depressziós tünetek súlyossága szignifikánsan nő az életkor emelkedésével (11,38-ról 13,55-re, $p=0,0001)$ és az egészségi állapot romlásával (10,67-ről 16,68-ra, $p<0,0001)$. Legalacsonyabb átlagértékkel a nagyon jó egészségi állapotú $(M=10,67)$ és a $20-29$ éves korosztály $(M=11,58)$ jellemezhető, legmagasabbal a rossz és nagyon rossz egészségi állapotú $(M=16,68)$, valamint a 60 év feletti korosztály $(M=13,55)$. [3. táblázat]

1. táblázat: A minta szocidemográfiai jellemzői

\begin{tabular}{|c|c|}
\hline \multirow{2}{*}{\multicolumn{2}{|c|}{$\begin{array}{r}\text { Szociodemográfiai háttérváltozók } \\
\text { Kor }\end{array}$}} \\
\hline & \\
\hline 20-29 év & $73(18,9)$ \\
\hline 30-39 év & $42(10,9)$ \\
\hline 40-49 év & $65(16,8)$ \\
\hline 50-59 év & $65(16,8)$ \\
\hline 60 év felett & $131(33,9)$ \\
\hline nem válaszolt & $10(2,6)$ \\
\hline \multicolumn{2}{|c|}{ Iskolai végzettség } \\
\hline alap & $35(9,1)$ \\
\hline közép & $224(58)$ \\
\hline felsőfok & $112(29)$ \\
\hline nem válaszolt & $15(3,9)$ \\
\hline \multicolumn{2}{|c|}{ Családi állapot } \\
\hline nőtlen/hajadon & $70(18,1)$ \\
\hline házas & $195(50,5)$ \\
\hline élettárssal él & $57(14,8)$ \\
\hline elvált & $36(9,3)$ \\
\hline özvegy & $15(9,3)$ \\
\hline nem válaszolt & $13(6,8)$ \\
\hline \multicolumn{2}{|c|}{ Nettó jövedelem } \\
\hline 100.000 Ft alatt & $38(9,8)$ \\
\hline $101.000-150.000 \mathrm{Ft}$ & $57(14,8)$ \\
\hline $151.000-200.000 \mathrm{Ft}$ & $51(13,2)$ \\
\hline $201.000-250.000 \mathrm{Ft}$ & $50(13)$ \\
\hline $251.000-300.000 \mathrm{Ft}$ & $26(6,7)$ \\
\hline 301.000 Ft felett & $81(21)$ \\
\hline nem válaszolt & $83(21,5)$ \\
\hline \multicolumn{2}{|c|}{ Szubjektív egészségi állapot } \\
\hline nagyon jó & $66(17,1)$ \\
\hline jó & $143(37)$ \\
\hline elfogadható & $141(36,5)$ \\
\hline rossz és nagyon rossz & $34(6,8)$ \\
\hline nem válaszolt & $2(0,5)$ \\
\hline
\end{tabular}


2. táblázat: WHO Általános Jóllét Skála átlagértékei a nettó jövedelem és a szubjektiv egészségi állapot mentén (ANOVA)

\begin{tabular}{|c|c|c|c|}
\hline & \multicolumn{3}{|c|}{$\begin{array}{c}\text { Teljes minta } \\
\mathrm{N}=386\end{array}$} \\
\hline & $\begin{array}{c}\text { Átlag } \\
(\mathrm{M})\end{array}$ & $\begin{array}{c}\text { szórás } \\
\text { (std) }\end{array}$ & $p$ \\
\hline \multicolumn{4}{|c|}{ Nettó jövedelem } \\
\hline $100.000 \mathrm{Ft}$ alatt $(\mathrm{N}=35)$ & 6,0 & 2,80 & \multirow{6}{*}{0,001} \\
\hline 101.000-150.000 Ft (N=55) & 8,69 & 3,49 & \\
\hline 151.000-200.000 Ft $(\mathrm{N}=48)$ & 8,00 & 3,91 & \\
\hline 201.000-250.000 Ft $(N=46)$ & 9,02 & 3,09 & \\
\hline 251.000-300.000 Ft $(N=25)$ & 7,24 & 3,65 & \\
\hline 301.000 Ft felett $(N=80)$ & 9,49 & 3,34 & \\
\hline \multicolumn{4}{|c|}{ Szubjektív egészségi állapot } \\
\hline nagyon jó (N=65) & 10,69 & 2,79 & \multirow{4}{*}{0,001} \\
\hline jó ( $N=137)$ & 8,91 & 3,40 & \\
\hline elfogadható (N=134) & 7,84 & 3,11 & \\
\hline rossz és nagyon rossz (N=33) & 5 & 3,33 & \\
\hline
\end{tabular}

Forrás: saját szerkesztés

3. táblázat: Rövidített Beck Depresszió Kérdőiv átlagértékei a kor és a szubjektív egészségi állapot mentén (ANOVA)

\begin{tabular}{|c|c|c|c|}
\hline & \multicolumn{3}{|c|}{$\begin{array}{c}\text { Teljes minta } \\
\mathrm{N}=386\end{array}$} \\
\hline & $\begin{array}{c}\text { Átlag } \\
\text { (M) }\end{array}$ & $\begin{array}{c}\text { szórás } \\
\text { (std) }\end{array}$ & p \\
\hline \multicolumn{4}{|c|}{ Kor } \\
\hline 20-29 év ( $N=68)$ & 11,38 & 3,42 & \multirow{5}{*}{0,002} \\
\hline 30-39 év $(N=36)$ & 11,08 & 2,60 & \\
\hline $40-49$ év $(N=61)$ & 12 & 3,37 & \\
\hline $50-59$ év $(N=62)$ & 12,16 & 4,15 & \\
\hline 60 év felett ( $N=119)$ & 13,55 & 5,13 & \\
\hline \multicolumn{4}{|c|}{ Szubjektív egészségi állapot } \\
\hline nagyon jó (N=63) & 10,67 & 2,694 & \multirow{4}{*}{$<0,000$} \\
\hline jó (N=132) & 11,58 & 3,46 & \\
\hline elfogadható ( $N=128)$ & 13,13 & 4,29 & \\
\hline rossz és nagyon rossz $(\mathrm{N}=31)$ & 16,68 & 5,99 & \\
\hline
\end{tabular}

Forrás: saját szerkesztés

\section{A Rövidített Stressz és Megküzdés Kérdőív élet} értelmességét mérő alskálája (BSCI-LM)

A teljes minta átlaga 12,311. Nem találtunk szignifikáns különbséget a nem $(p=0,616)$, a különböző iskolai végzettség $(p=0,256)$, a családi állapot $(p=0,881)$ és a korcsoportok $(p=0,208)$ szerint. $\mathrm{Az}$ átlagérték szignifikánsan emelkedik a nettó jövedelem emelkedésével (10,97-ről 12,95-re, $p=0,048)$ és az egészségi állapot egyre kedve- zőbb megítélésével (9,93-ról 13,27-re, p=0,0001). [4. táblázat]

\section{Észlelt Stressz Kérdőív}

Az Észlelt Stressz Kérdőív átlaga a teljes mintán: 4,59 . Nem találtunk szignifikáns különbséget a nem $(p=0,12)$, ez életkor $(p=0,52)$, a különböző iskolai végzettség $(p=0,12)$ és a családi állapot $(p=0,89)$ tekintetében. Az átlagérték szignifikánsan emel- 
kedik a nettó jövedelem csökkenésével (3,8-ról 4,93-ra, p<0,005), és az egészségi állapot egyre kedvezőtlenebb megítélésével (3,53-ról 6,3-ra, p=0,05). [5. táblázat]

\section{Lelki Egészség Kérdőív (GHQ)}

A Lelki Egészség kérdőíven a leggyakoribb értékelési módszer alapján legalább 5 pontot ért el a megkérdezettek 10,6\%-a. Ez az arány megegyezik a magyarországi illesztett minta átlagával. A tünetek átlagos pontszáma: 1,62. Nem találtunk szignifikáns különbséget az életkor ( $p=0,99)$, az iskolai végzettség $(p=0,92)$ és a családi állapot $(p=0,49)$ tekintetében. [6. táblázat] A nők pontszáma szignifikánsan magasabb, mint a férfiaké (1,75 vs. $1,41, p=0,03)$, és egyre csökken a nettó jövedelem emelkedésével (1,58-ról 1,22-re, $p=0,03)$ és az egészségi állapot egyre kedvezőbb megítélésével (2,87-ről 1,36-ra, $p<0,00)$. [6. táblázat]

4. táblázat: A Röviditett Stressz és Megküzdés Kérdőiv élet értelmességét mérő alskálájának átlagértékei a nettó jövedelem és a szubjektiv egészségi állapot mentén (ANOVA)

\begin{tabular}{|c|c|c|c|}
\hline & \multicolumn{3}{|c|}{$\begin{array}{c}\text { Teljes minta } \\
\mathrm{N}=386\end{array}$} \\
\hline & $\begin{array}{c}\text { Átlag } \\
(\mathrm{M})\end{array}$ & $\begin{array}{c}\text { szórás } \\
\text { (std) }\end{array}$ & $p$ \\
\hline \multicolumn{4}{|c|}{ Nettó jövedelem } \\
\hline $100.000 \mathrm{Ft}$ alatt $(\mathrm{N}=34)$ & 10,97 & 3,44 & \multirow{6}{*}{0,048} \\
\hline 101.000-150.000 Ft (N=52) & 12,83 & 2,87 & \\
\hline 151.000-200.000 Ft $(N=47)$ & 12,15 & 2,99 & \\
\hline 201.000-250.000 Ft (N=45) & 12,36 & 2,93 & \\
\hline 251.000-300.000 Ft $(\mathrm{N}=21)$ & 12,33 & 2,67 & \\
\hline 301.000 Ft felett ( $N=74)$ & 12,95 & 2,84 & \\
\hline \multicolumn{4}{|c|}{ Szubjektív egészségi állapot } \\
\hline nagyon jó (N=60) & 13,27 & 2,87 & \multirow{4}{*}{0,000} \\
\hline jó ( $N=134)$ & 12,62 & 2,63 & \\
\hline elfogadható (N=123) & 11,77 & 3,06 & \\
\hline rossz és nagyon rossz ( $\mathrm{N}=29)$ & 9,93 & 3,58 & \\
\hline
\end{tabular}

Forrás: saját szerkesztés

5. táblázat: Az Észlelt Stressz Kérdőív átlagértékei a nettó jövedelem és a szubjektiv egészségi állapot mentén (ANOVA)

\begin{tabular}{|c|c|c|c|}
\hline & \multicolumn{3}{|c|}{$\begin{array}{l}\text { Teljes minta } \\
\quad \mathrm{N}=386\end{array}$} \\
\hline & $\begin{array}{c}\text { Átlag } \\
(\mathrm{M})\end{array}$ & $\begin{array}{c}\text { szórás } \\
\text { (std) }\end{array}$ & $\mathrm{p}$ \\
\hline \multicolumn{4}{|c|}{ Nettó jövedelem } \\
\hline $100.000 \mathrm{Ft}$ alatt $(\mathrm{N}=34)$ & 4,93 & 2,34 & \multirow{6}{*}{0,05} \\
\hline 101.000-150.000 Ft (N=52) & 4,47 & 2,78 & \\
\hline 151.000-200.000 Ft $(N=47)$ & 4,44 & 2,96 & \\
\hline 201.000-250.000 Ft (N=45) & 4,74 & 2,6 & \\
\hline 251.000-300.000 Ft $(\mathrm{N}=21)$ & 5,7 & 2,95 & \\
\hline 301.000 Ft felett $(N=74)$ & 3,8 & 2,84 & \\
\hline \multicolumn{4}{|c|}{ Szubjektív egészségi állapot } \\
\hline nagyon jó (N=65) & 3,53 & 2,66 & \multirow{4}{*}{0,000} \\
\hline jó (N=136) & 4,14 & 2,62 & \\
\hline elfogadható (N=132) & 5,15 & 2,6 & \\
\hline rossz és nagyon rossz $(\mathrm{N}=30)$ & 6,3 & 4,08 & \\
\hline
\end{tabular}

Forrás: saját szerkesztés 
6. táblázat: A Lelki Egészség Kérdőiv átlagértékei a nettó jövedelem, a szubjektiv egészségi állapot és a nem mentén (ANOVA)

\begin{tabular}{|c|c|c|c|}
\hline & \multicolumn{3}{|c|}{$\begin{array}{c}\text { Teljes minta } \\
\mathrm{N}=382\end{array}$} \\
\hline & $\begin{array}{c}\text { Átlag } \\
(\mathrm{M})\end{array}$ & $\begin{array}{c}\text { szórás } \\
\text { (std) }\end{array}$ & $p$ \\
\hline \multicolumn{4}{|c|}{ Nem } \\
\hline férfi ( $N=143)$ & 1,41 & 1,68 & \multirow[t]{2}{*}{0,05} \\
\hline nő (N=244) & 1,75 & 2,16 & \\
\hline \multicolumn{4}{|c|}{ Nettó jövedelem } \\
\hline 100.000 Ft alatt $(N=36)$ & 1,58 & 2,43 & \multirow{6}{*}{0,03} \\
\hline 101.000-150.000 Ft $(N=56)$ & 2,03 & 2,49 & \\
\hline 151.000-200.000 Ft $(\mathrm{N}=50)$ & 1,8 & 2,4 & \\
\hline 201.000-250.000 Ft $(N=48)$ & 1,3 & 1,61 & \\
\hline 251.000-300.000 Ft $(\mathrm{N}=26)$ & 2,65 & 2,74 & \\
\hline 301.000 Ft felett $(N=50)$ & 1,22 & 1,38 & \\
\hline \multicolumn{4}{|c|}{ Szubjektív egészségi állapot } \\
\hline nagyon jó (N=65) & 1,36 & 1,25 & \multirow{4}{*}{0,000} \\
\hline jó (N=144) & 1,38 & 1,55 & \\
\hline elfogadható ( $N=141$ ) & 1,7 & 2,26 & \\
\hline rossz és nagyon rossz $(\mathrm{N}=33)$ & 2,87 & 3,09 & \\
\hline
\end{tabular}

Forrás: saját szerkesztés

\section{MEGBESZÉLÉS}

Az 5 tételes WHO Általános Jóllét Skála átlagértéke kicsit magasabb a Hungarostudy 2002 kutatásban talált értéknél. ${ }^{24}$ A Hungarostudy 2002 kutatásban talált és a 2014-es egészségfelmérés adatokhoz hasonlóan eredményeink szerint az általános jóllét átlagértéke emelkedik a nettó jövedelem és az egészségi állapot egyre kedvezőbb megítélésével. ${ }^{14,26} \mathrm{~A}$ nagyon jó egészségi állapotú személyek átlagértéke a duplája a rossz és nagyon rossz egészségi állapotú személyekének. A korábbi hazai vizsgálatokban talált nemek közötti, életkorral és iskolai végzettséggel kapcsolatos különbséget jelen kutatásunk nem tudja megerősíteni. 14,26,27

A Rövidített Beck Depressziós Kérdőív teljes minta átlaga enyhe depressziós állapotot jelez, és a depressziós tünetek súlyossága szignifikánsan nő az életkor emelkedésével és az egészségi állapot romlásával. Eredményeink összhangban állnak a 2014-es magyarországi egészségfelmérés (ELEF) adataival, melyek szerint az életkor növekedésével a nők és a férfiak esélye egyaránt növekszik a depresszió kialakulására, amely a legidősebbek körében a leggyakoribb. ${ }^{26} \mathrm{~A}$ korábbi hazai kutatásokban talált depressziós tünetek súlyossága és a nemek közötti, valamint az anyagi helyzettel, az iskolai végzettséggel és a családi állapottal kapcsolatos különbségeket eredményeink nem erősítik meg. ${ }^{26,27,28}$

A Rövidített Stressz és Megküzdés Kérdőív élet értelmességét mérő alskáláján a teljes minta átlaga kicsit magasabb a korábbi magyarországi eredményekhez képest. ${ }^{16} \mathrm{~A}$ nők átlagértéke a hazai adatokkal összhangban kicsit magasabb, mint a férfiaké, a különbség azonban nem szignifikáns. ${ }^{16} \mathrm{Az}$ élet értelmessége és a nem közötti összefüggéssel kapcsolatos korábbi eredmények azonban eltérőek. ${ }^{29,30,31,32,33}$ Eredményeink szerint a nettó jövedelem növekedésével és az egészségi állapot egyre kedvezőbb megítélésével emelkedik az átlagérték. A nagyon jó egészségi állapotú személyek átlagértéke $\mathrm{kb}$. a duplája a nagyon rossz egészségi állapotú személyek átlagértékének. Eredményeink összhangban állnak a 2014-ben végzett ELEF eredményeivel. ${ }^{26}$ Jelen vizsgálatunkban nem találtunk szignifikáns különbséget az életkor szerinti csoportok átlagértékeiben az élet értelmességét mérő tételek kapcsán, de a korábbi vizsgálatok eredményei szintén vegyesek. ${ }^{29,30,31,33,34,35,36,37,38,39}$

Észlelt Stressz Kérdőív átlagértéke $(4,59)$ a magyarországi életkori átlaghoz $(6,6)$ képest jelentősen 
kedvezőbb képet mutat. ${ }^{11}$ A nemi különbség nem jelentkezett az korábbi kutatásokban sem, ahogy mi sem találtunk szignifikáns eltérést a férfiak és a nők között. Ugyanígy, az életkor és az iskolai végzettség tekintetében sem volt különbség a mintánkban a különböző csoportok közt, ahogyan a validáláskor sem jelent ez meg magyarországi mintán. ${ }^{11}$ Nemzetközi tanulmányokban is hasonló eredmények születtek az észlelt stressz tekintetében. Egy 2010es kínai vizsgálatban, melynek célja a dohányzás, a stressz és a kardiovaszkuláris tünetek közötti összefüggés keresése volt, a 4 tételes Észlelt Stressz Kérdőív használatakor 6,25-ös átlageredményt kaptak hasonló életkori mintán. Szintén nem volt szignifikáns különbség nők és férfiak között. ${ }^{40}$ A francia verzió 2012-es validálásakor, egy több mint 500 főt vizsgáló mintán az átlag 5,4 lett, nemi különbséget pedig szintén nem találtak. ${ }^{41} \mathrm{~A}$ testi tünetek számát illetően a korábbi kutatásokban közepesen erős korrelációt mutattak ki az észlelt stressz szintjével. ${ }^{11} \mathrm{Mi}$ az egészségi állapot önbecslését használtuk első körben ennek a konstruktumnak a megragadására, ahol szignifikáns eltérést találtunk, vagyis azok a személyek, akik saját egészségi állapotukat nagyon rossznak minősítik, szignifikánsan magasabb észlelt stressz pontszámot kaptak. Vizsgálatunkban szignifikáns különbséget láttunk a jövedelmi kategóriák alapján létrehozott csoportok között, míg a különböző jövedelmi csoportoknál érdekes mintázatot fedeztünk fel a stressz szintjével kapcsolatban. Nem volt korreláció a stressz szintje és a jövedelem között, vagyis nem csökken a stressz szintje a jövedelem növekedésével. A 250.000-300.000 Ft-os jövedelmi kategóriába esők élik meg a legjelentősebb mértékű stresszt. Az ez alatti jövedelmi kategóriák stresszszintje közt nem volt szignifikáns különbség, de az a fölötti jövedelmi kategória viszont szignifikánsan alacsonyabb stresszszintet ért el. Mivel korábban az észlelt stresszt nem vizsgálták a jövedelem tekintetében, ennek magyarázata további feladataink közé tartozik, de úgy tűnik, hogy a felső középosztály éli meg leginkább nyomásként életszínvonalának megtartását.

Jelen vizsgálatban a Lelki Egészség Kérdőív alkalmazásának fő célja a funkcionalitás-csökkenést jelentő mentális problémák előfordulásának meghatározása volt. A Lelki Egészség Kérdőíven a leggyakoribb értékelési módszer alapján legalább 5 pontot ért el a megkérdezettek 10,6\%-a. Ez az arány megegyezik a magyarországi illesztett minta átlagával. ${ }^{6}$ A tünetek átlagos pontszáma: 1,62. Mintánkban szignifikáns eltérést láttunk a férfiak és nők között, mely szintén megegyezik a korábbi, országos lakossági egészségfelmérés eredményeivel. A jövedelem és a lelki egészség összefüggése szintén kimutatható volt saját vizsgálatunkban, ahogyan az országos lakossági egészségfelmérés alkalmával is. ${ }^{6} \mathrm{~A}$ mintázat azonban eltérő volt, mivel a mi vizsgálatunkban a jövedelem növekedésével nem növekedett a lelki egészség. A stresszinthez hasonlóan a 250.000300.000 Ft-os jövedelmi kategóriába tartozók mentális funkciócsökkenése a legkifejezettebb. Egy 2019-es norvég vizsgálatban hasonló eredményeket kaptak, miszerint a magasabban kvalifikáltabb munkavállalók lelkiegészség-mutatói szignifikánsabban rosszabbak lettek. ${ }^{42} \mathrm{Az}$ egészségi állapot önbecslése alapján, akik magukat a rossz vagy nagyon rossz kategóriába sorolják, szignifikánsan nagyobb funkciócsökkenést értek el mentális állapotukban. Az országos lakossági egészségfelmérésen szintén összefüggést találtak az egészségi állapot és a lelki egészség között. ${ }^{6}$ Akik a saját egészségi állapotukat rosszabbnak ítélték, rosszabb lelki egészség mutatókkal rendelkeznek. Ehhez hasonlóan kapcsolatot találtak a Lelki Egészség Kérdőív eredményei és a szomatikus tünetek előfordulási gyakorisága közt egy 2019-es iráni kutatásban, ahol atléta és nem atléta nőket vizsgáltak. Ugyanebben a vizsgálatban a különböző jövedelmi csoportok közti különbségek hasonlóan alakultak saját eredményeinkhez viszonyítva. ${ }^{43}$

\section{KÖVETKEZTETÉS}

Eredményeink szerint az idősebb kor, a kedvezőtlennek ítélt egészségi állapot és anyagi helyzet negatív módon befolyásolja a lelki egészséget. Éppen ezért az idősek, a betegek és a kedvezőtlen anyagi helyzetben levő személyek pszichés támogatására az egészségügyi és szociális szakmában dolgozóknak kiemelt figyelmet kell szentelni.

Vizsgálatunk eredményei alapján azt látjuk, hogy a szubjektíven megélt élethelyzet kifejezettebb hatással van a stressz szintjére és a lelki egészségre, mint az objektív demográfiai mutatók. Fontos felhívni a figyelmet a felső középosztály helyzetére, akik vizsgálatunkban rosszabb lelkiegészség-mutatókkal rendelkeznek. 


\section{HIVATKOZÁSOK}

${ }^{1}$ Pikó B. Az egészségi állapot komplexitása és mérési lehetőségei. LAM, 1996;6:474-477.,

2 Pikó B. Teaching the mental and social aspects of medicine in Eastern Europe: Role of the WHO definition of health. Adm Pol Ment Health, 1999;26: 435-438.

${ }^{3}$ Atkinson RC, Hilgard E. Pszichológia (Harmadik, átdolgozott kiadás) Oziris Kiadó, Budapest, 2005.

${ }^{4}$ Buda B. A lélek egészsége. A mentálhigiéné alapkérdései. Nemzeti Tankönyvkiadó, Budapest, 2003.

${ }^{5}$ World Health Organization (2009). Health in times of global economic crisis: Implications for the WHO European Region. http://www.euro.who.int/ data/assets/pdf file/0006/66957/RC59 edoc07.pdf (Elérve: 2019. 07. 16.) ${ }^{6}$ Örkényi Á. Lelki egészség. Országos Lakossági Egészségfelmérés (OLEF) 2003. Országos Epidemiológiai Központ, Budapest, 2005.

${ }^{7}$ Ádány R. Megelőző orvostan és népegészségtan. Medicina kiadó, Budapest, 2011.

${ }^{8}$ Selye $\mathrm{H}$. The stress concept and some of its implications. Human stress and cognition: An information processing approach, Chichester, Eng, New York, 1979.

${ }^{9}$ Kopp MS, Réthelyi J. Where psychology meets physiology: chronic stress and premature mortality - the CentralEastern European health paradox. Brain Research Bulletin, 2004;62(5):351-367.

${ }^{10}$ Cohen S, Kamarck T, Mermelstein R. A global measure of perceived stress. Journal of Health and Social Behavior, 1983;24:385-396.

${ }^{11}$ Stauder A, Konkolÿ Thege B. Az észlelt stressz kérdőív (PSS) magyar verziójának jellemzői. Mentálhigiéné és Pszichoszomatika, 2006;7(3):203-216.

${ }^{12}$ Goldberg DP, Blackwell B. Psychiatric illness in general practice: A detailed study using a new method of case identification. British Medical Journal, 1970;1:439-443.

${ }^{13}$ Goldberg DP. The detection of psychiatric illness by questionnaire. Oxford University Press, London, 1972.

${ }^{14}$ Susánszky É, Konkolÿ Thege B, Stauder A. A WHO Jól-lét kérdőív (WBI-5) magyar változatának validálása a Hungarostudy 2002 országos lakossági egészségfelmérés alapján. Mentálhigiéné és Pszichoszomatika, 2006;7(3):247255. DOI: 10.1556/Ment·. 7.2006.3.8

${ }^{15}$ Beck AT, Steer RA, Brown GK. Manual for the Beck Depression Inventory-II. San Antonio, TX: Psychological Corporation, 1996.

${ }^{16}$ Konkolÿ Thege B, Martos T, Skrabski Á, et al. A Rövidített Stressz és Megküzdés kérdőív Élet értelmességét mérő alskálájának (BSCI-LM) pszichometriai jellemzői. Mentálhigiéné és Pszichoszomatika, 2008;9(3):243-261. DOI: 10.1556/Mentál.9.2008.3.4

${ }^{17}$ Rózsa S, Szádóczky E, Füredi J. A Beck Depresszió Kérdőív rövidített változatának jellemzői hazai mintán. Psychiatria Hungarica, 2001;16(4):384.402.

${ }^{18}$ Beck AT, Beck RW. Shortened version of BDI. Postgraduate Medicine, 1972;52:81-85.

${ }^{19}$ Kopp M. Beck Depresszió Kérdőív. In: Perczel Forintos D, Ajtay Gy, Kiss Zs. (editor). Kérdőívek, becslőskálák a klinikai pszichológiában. Semmelweis Kiadó, Budapest, 2007. pp 44-45.

${ }^{20}$ Rahe RH, Tolles RL. The Brief Stress and Coping Inventory: a useful stress management instrument. International Journal of Stress Management, 2002;9(2):61-70.

${ }^{21}$ Rózsa S, Kő N, Csoboth Cs. et al. Stressz és megküzdés. A Rahe-féle Rövidített Stressz és Megküzdés Kérdőívvel szerzett hazai eredmények ismertetése. Mentálhigiéné és Pszichoszomatika, 2005;6(4):275-294.

22 Brassai L, Pikó B. Protektív pszichológiai jellemzők szerepe a serdülők egészséggel kapcsolatos magatartásában. Mentálhigiéné és Pszichoszomatika, 2007;8:211-227.

${ }^{23}$ Skrabski Á, Kopp M, Rózsa S. A koherencia mint a lelki és testi egészség alapvető meghatározója a mai magyar társadalomban. Mentálhigiéné és Pszichoszomatika, 2004;5:7-25.

${ }^{24}$ Rózsa S, Réthelyi J, Stauder A. et al. A Hungarostudy 2002 országos reprezentatív felmérés általános módszertana és a fel-használt tesztbattéria pszichometriai jellemzői. Psychiatria Hungarica, 2003;18:83-94.

${ }^{25}$ Idler EL, Benyamini Y. Self-rated health and mortality: a review of twenty-seven community studies. Journal of Health and Social Behavior, 1997;38 (1): 21-37.

${ }^{26}$ Központi Statisztikai Hivatal. A 2014-ben végrehajtott európai lakossági egészségfelmérés eredményei -Összefoglaló Adatok. http://www.ksh.hu/docs/hun/xftp/idoszaki/elef/elef2014 osszefoglalo.pdf (Elérve: 2019. 07. 27.)

${ }^{27}$ Dinyáné Szabó M, Pusztai G. Az Egészségügyi Világszervezet öttételes jól-lét kérdőívének vizsgálata a Semmelweis Egyetem elsőéves hallgatóinak körében. Orvosi Hetilap, 2016;157:1762-1768.

${ }^{28}$ Kopp M, Martos T. A magyarországi gazdasági növekedés és a társadalmi jóllét, életminőség viszonya. Magyar Pszichofiziológiai és Egészséglélektani Társaság. 2011; pp. 26.

http://ess.tk.mta.hu/wp-content/uploads/2013/04/kopp gazdasagi novekedes.pdf (Elérve: 2019. 07. 01.) 
${ }^{29}$ Längle A, Orgler C, Kundi M. The Existence Scale: A new approach to assess the ability to find personal meaning in life and to reach existential fulfillment. European Psychotherapy, 2003;4(1):135-151.

${ }^{30}$ Konkolÿ Thege B, Martos T. Reliability and validity of the shortened Hungarian version of the Existence Scale.

Existenzanalyse, 2008;25 (1):19-23.

${ }^{31}$ Konkolÿ Thege B, Martos T. Az Életcél-kérdőív magyar változatának jellemzői. Mentálhigiéné és Pszichoszomatika, 2006; 7: 153-169.

${ }^{32}$ Crumbaugh JC, Maholick LT.: An experimental study in existentialism: The psychometric approach to Frankl's concept of noogenic neurosis. Journal of Clinical Psy-chology, 1964;20: 200-207.

${ }^{33}$ Reker GT. Meaning in life of young, middle-aged, and older adults: Factorial va-lidity, age, and gender invariance of the Personal Meaning Index (PMI). Personality and Individual Differences, 2005;38:71-85.

${ }^{34}$ Steger MF, Frazier P, Oishi S. The Meaning in Life Questionnaire: Assessing the presence of and search for meaning in life. Journal of Counseling Psychol-ogy, 2006;53(1):80-93.

${ }^{35}$ Van Ranst N, Marcoen A. Meaning in life of young and elderly adults: An exami-nation of the factorial validity and invariance of the Life Regard Index. Personality and Individual Differences, 1997;22:877-884.

${ }^{36}$ Lukas ES. Logo-Test. Test zur Messung von „innerer Sinnerfüllung“ und „existenziel-ler Frustration”. Handanweisung, Deuticke, Wien, 1986.

${ }^{37}$ Meier A, Edwards H. Purpose-In-Life test: Age and sex differences. Journal of Clinical Psychology, 1974;30:384-386.

${ }^{38}$ Reker GT, Cousins JB. Factor structure, construct validity and reliability of the Seeking of Noetic Goals (SONG) and Purpose in Life (PIL) tests. Journal of Clinical Psy-chology, 1979;35(1):85-91.

${ }^{39}$ Reker GT, Fry PS. Factor structure and invariance of personal meaning measu-res in cohorts of younger and older adults. Personality and Individual Differences, 2003;35:977-993.

${ }^{40}$ Leung Doris YP, Tai-hing Lam, and Sophia SC Chan. Three versions of Perceived Stress Scale: validation in a sample of Chinese cardiac patients who smoke. BMC public health,2010; 10.1, 513.

${ }^{41}$ Lesage, F. X., Berjot, S., \& Deschamps, F. Psychometric properties of the French versions of the Perceived Stress Scale. International journal of occupational medicine and environmental health, 2012; 25(2), 178-184.

${ }^{42}$ Geirdal, A. $\varnothing$., Nerdrum, P., \& Bonsaksen, T. The transition from university to work: what happens to mental health? A longitudinal study. BMC psychology, 2019; 7(1), 65.

${ }^{43}$ Alamdarloo, G. H., Cheric, M. C., Doostzadeh, M., \& Nazari, Z. The comparison of general health in athlete and non-athlete women. Health psychology research, 2019; 7(1). 